\title{
Pattern of protein production by bovine corpora lutea during luteolysis and characterization of expression of two major secretory products of regressing corpora lutea
}

\author{
J. L. Juengel ${ }^{1}$, G. W. Smith ${ }^{1}$, M. F. Smith ${ }^{1 *}$, R. S. Youngquist ${ }^{2}$ \\ and H. A. Garverick ${ }^{1}$ \\ Departments of ${ }^{1}$ Animal Sciences and ${ }^{2}$ Veterinary Medicine and Surgery, University of \\ Missouri, Columbia, MO 65211, USA
}

\begin{abstract}
Although the decrease of progesterone in serum and in luteal tissue during luteal regression is well characterized, relatively little is known about changes in proteins produced by the corpus luteum during this time. The first objective was to examine changes in patterns of protein secretion that might be associated with functional and structural luteal regression. The second objective was to characterize the expression of two major secretory products of regressing corpora lutea. Thirty normally cyclic heifers were randomly assigned at day $15-16$ of the oestrous cycle (oestrus $=$ day 0 ) to be ovariectomized at $0 \mathrm{~h}($ no PGF $2 a ; n=5)$ or at $4,8,12,24$ or $48 \mathrm{~h}$ after $\mathrm{PGF}_{2 \alpha}$-induced luteal regression ( $n=5$ per time point). Total cellular RNA was isolated from tissue frozen at the time of ovariectomy. Thin slices $(<1 \mathrm{~mm})$ of tissue were placed in methionine-deficient minimum essential media with $\left[{ }^{35} \mathrm{~S}\right]$ methionine and placed in a humidified $\mathrm{CO}_{2}$ incubator at $38^{\circ} \mathrm{C}$. Media and tissues were collected $6 \mathrm{~h}$ later. Changes in profiles of secreted proteins were analysed by onedimensional SDS-PAGE. A number of proteins (relative molecular mass ranging from 14300 to 200000$)$ were produced by luteal tissue at each time point $(0-48 \mathrm{~h})$. The major secretory proteins had relative molecular masses of approximately $21500,28200,43700$ and 46000 . Secretion of the relative molecular mass 46000 protein(s) increased $(P<0.05)$ between 4 and $24 \mathrm{~h}$ after $\mathrm{PGF}_{2 \alpha}$ injection compared with the $0 \mathrm{~h}$ group. Western blot analyses with either tissue inhibitor of metalloproteinase- 1 or tissue inhibitor of metalloproteinase- 2 antisera detected immunoreactive proteins of relative molecular mass 28200 and 21500 , respectively. Concentrations of mRNA encoding tissue inhibitor of metalloproteinases- 1 increased $(P<0.01)$ by $8 \mathrm{~h}$ after $\mathrm{PGF}_{2 \alpha}$ injection, remained stable $(P>0.20)$ through $24 \mathrm{~h}$ and decreased $(P<0.05)$ by $48 \mathrm{~h}$ after $\mathrm{PGF}_{2 \alpha}$. Concentrations of tissue inhibitor of metalloproteinases- 2 mRNA were highest $(P<0.05)$ at $8 \mathrm{~h}$ after $\mathrm{PGF}_{2 \alpha}$ injection and lowest $(P<0.05) 48 \mathrm{~h}$ following induction of luteolysis. In summary, the profile of luteal protein production changed during luteolysis and two secretory products (tissue inhibitor of metalloproteinases- $I$ and -2) were identified. Metalloproteinase inhibitors may have an important role in tissue remodelling during structural luteolysis.
\end{abstract}

\section{Introduction}

Prostaglandin $\mathrm{F}_{2 \alpha}\left(\mathrm{PGF}_{2 \alpha}\right)$ of uterine origin causes luteal regression in several species including cattle (for review see Knickerbocker et al., 1988). $\mathrm{PGF}_{2 \alpha}$-induced luteolysis may involve any of the following mechanisms: (1) decrease in blood flow (Niswender, 1981), (2) direct action on luteal cells (Hansel et al., 1991; Wiltbank et al., 1991); (3) production of oxygen radicals (Riley and Behrman, 1991); or (4) recruitment of immune cells (Murdoch et al., 1988). The precise mechanisms

* Correspondence and reprint requests.

Received 14 June 1993. associated with luteolysis are not clearly understood; however, complex communication between different luteal cell populations seems likely. Hansel et al. (1991) proposed that luteal cell types cooperate to obtain peak progesterone secretion during the luteal phase and that loss of this positive interaction could play a role in luteolysis. In addition, large luteal cells that contain large numbers of $\mathrm{PGF}_{2 \alpha}$ receptors may regulate small luteal cell function during luteolysis in sheep, since the number of small cells, which contain few $\mathrm{PGF}_{2 \alpha}$ receptors, decreased before that of the large cells (Braden et al., 1988). The agents responsible for communication between luteal cells are not known, but may include steroids, prostaglandins, and proteins. Morphological (O'Shea et al., 1977; Sawyer et al., 1990) and 
biochemical (Juengel ef al., 1993) evidence indicates that apoptosis is associated with luteal cell death. Apoptosis is a process of cell death that eliminates a distinct population of cells by activation of metabolic events within the cells themselves. In some systems apoptosis requires synthesis of specific proteins (Arends and Wyllie, 1991); changes in protein synthesis may therefore occur during luteolysis. One morphological characteristic of cells undergoing apoptosis is detachment from the extracellular matrix and subsequent loss of contact with neighbouring cells (Kerr et al., 1972). Metalloproteinases and their inhibitors are extensively involved in regulation of extracellular matrix remodelling (Woessner, 1991) and thus may be involved in control of cell death and tissue reorganization during luteolysis.

One aspect of luteal regression that has not been examined is the changes in protein production that occur during luteolysis. The specific objectives of this study were: (1) to determine changes in protein production during luteolysis and (2) to characterize the expression of two major secretory products of regressing corpora lutea (tissue inhibitor of metalloproteinases- $I$ (TIMP-I) and -2 (TIMPs-2)).

\section{Materials and Methods}

\section{Animal care}

All procedures described where animals were used were approved by the University of Missouri Animal Care and Use Committee (Protocol no. 1903).

\section{Experimental design}

Beef heifers (15-24 months of age) exhibiting normal oestrous cycles (18-24 days) were housed in dry pens and fed corn silage with supplemental grain to meet National Research Council growth requirements. Heifers were randomly assigned to a treatment group after being observed in standing oestrus $($ day $=0$ ). On day $15-16$, heifers were either ovariectomized $(n=5 ; 0 \mathrm{~h})$ or given $25 \mathrm{mg}$ PGF $_{2 \alpha}$ (Lutalyse: Upjohn Co., Kalamazoo, MI) to induce luteolysis. Heifers that received $\mathrm{PGF}_{2 \alpha}$ were ovariectomized at $4,8,12,24$ or $48 \mathrm{~h}(n=5$ per time point) after injection of $\mathrm{PGF}_{2 \alpha}$. Blood was collected daily for 4 days preceding ovariectomy or $\mathrm{PGF}_{2 \alpha}$ injection, at the time of $\mathrm{PGF}_{2 \alpha}$ injection, and at ovariectomy. Concentration of progesterone in all sera was determined by radioimmunoassay (Copelin et al., 1989) in two assays; intra-assay coefficients of variation averaged $15.8 \%$ and the inter-assay coefficient of variation was $2.9 \%$.

\section{Ovary removal and tissue culture}

Lidocaine $(2 \%)$ was used locally to anaesthetize the surgical site. Ovaries containing corpora lutea were removed by aseptic technique with an ecraseur inserted through a flank incision, rinsed in sterile saline and transported to the laboratory. Corpora lutea were blunt dissected from ovaries and weighed. Thin slices (approximately $1 \mathrm{~mm}$ ) were obtained from the central portion of the gland with a hand microtome and tissue explants (one slice, $10-40 \mathrm{mg}$ per slice) were cultured in $0.5 \mathrm{ml}$ of methionine deficient media (MEM; Sigma, St Louis, MO) with $50 \mu \mathrm{Ci} \mathrm{L}-\left[{ }^{35} \mathrm{~S}\right]$ methionine (cell labelling grade, Amersham, Arlington, Heights, IL) for $6 \mathrm{~h}$ in a humidified $5 \% \mathrm{CO}_{2} 38^{\circ} \mathrm{C}$ incubator on an orbital shaker. The remaining tissue was frozen in liquid $\mathrm{N}_{2}$ and stored at $-70^{\circ} \mathrm{C}$ until DNA and RNA analysis. Tissues were frozen or cultures were initiated within $30 \mathrm{~min}$ of removal of ovaries.

\section{Analysis of secreted proteins}

Media were collected at the end of the $6 \mathrm{~h}$ culture, centrifuged at low speed to remove any tissue debris, and stored at $-70^{\circ} \mathrm{C}$. Samples were lyophilized, resuspended in reducing gel loading buffer, and trichloroacetic acid precipitable radioactivity determined. Equivalent amounts of radioactivity per lane were separated by PAGE (12.5\% gel; Moor et al., 1981). Radiolabelled proteins were visualized by fluorography using Kodak X-Omat AR-5 film (Rochester, NY). The percentage of total radiolabelled protein represented in each major protein band was determined by densitometry.

\section{Western blot analysis}

Secreted proteins were collected from corpora lutea removed $12 \mathrm{~h}$ after $\mathrm{PGF}_{2 \alpha}$-induced luteolysis. Conditions for culture were the same as those outlined above except that $\mathrm{L}-\left[{ }^{35}\right.$ S]methionine was replaced with non-labelled methionine. Reduced proteins $(100 \mu \mathrm{g})$ were separated by PAGE $(10 \% \mathrm{gel})$, and transferred to nitrocellulose (Fisher Scientific, St Louis, $\mathrm{MO}$ ) by electroblotting. Lanes were blocked with $5 \%$ non-fat dry milk (NFDM) in Tris-buffered saline with $0.05 \%$ Tween (TBS-T, Fisher Scientific) at room temperature for $4 \mathrm{~h}$. Nitrocellulose strips were washed (three times, $5 \mathrm{~min}$ each) in TBS-T and incubated with normal rabbit serum or antisera (described below) in TBS-T with I\% NFDM at room temperature overnight. Immunoreactive TIMP-I was detected by incubating nitrocellulose strips in IgG purified normal rabbit serum (control; 1:1000 dilution) or in rabbit anti-human TIMP-I serum (1:3600 dilution, donated by I. M. Clarke, Cambridge, UK and funded by Smith Kline Beecham Pharmaceuticals, Philadelphia, PA). Immunoreactive TIMP-2 was detected by incubating nitrocellulose strips in normal rabbit serum (control; 1:750 dilution) or rabbit anti-human TIMP-2 antisera (1:750 dilution; donated by W. G. Stetler-Stevenson, Bethesda, MD). Strips were washed (three times, $5 \mathrm{~min}$ each) in TBS-T and incubated with goat anti-rabbit immunoglobin conjugated to horseradish peroxidase (Bio-Rad Laboratories, Richmond, CA) at $1: 3000$ dilution in TBS-T with $1 \%$ NFDM for $4 \mathrm{~h}$ at room temperature. Strips were washed (once in TBS-T, 5 min; twice in TBS, $5 \mathrm{~min}$ ) and transferred to TBS containing 4-chloro- Inaphthol (Sigma) and $\mathrm{H}_{2} \mathrm{O}_{2}$ (Fisher Scientific).

\section{Preparation of probes}

Complementary DNA probes for TIMP-1 (Smith et al., 1994) and TIMP-2 (Smith et al., 1992) isolated from an ovine corpus luteum cDNA library were used for hybridization. The $900 \mathrm{bp}$ TIMP-1 cDNA and $428 \mathrm{bp}$ TIMP-2 cDNA were 
random prime labelled with the Klenow fragment of DNA polymerase 1 (Multi Prime Labelling System, Amersham) to a specific activity of approximately $1.8 \times 10^{8} \mathrm{cpm} \mathrm{\mu g}^{-1} \mathrm{DNA}$ with $\alpha\left[^{32} \mathrm{P}\right] \mathrm{dCTP}$ (3000 Ci mmol ${ }^{-1}$, Amersham).

\section{Northern and dot blot analysis}

Total cellular RNA was isolated by the method of Chomczynski and Sacchi (1987). The amount of DNA was determined by the method of Labarca and Paigen (1980). For northern analysis, equal concentrations of total cellular RNA from each sample were combined by treatment $(0,4,8,12,24$ and 48 h). Five (TIMP-2) or 7.5 (TIMP-1) $\mu$ g total cellular RNA from combined samples, total cellular RNA isolated from bovine corpora lutea (positive control) and bovine spleen (negative control) were subjected to electrophoresis in a 1.5\% agarose formaldehyde gel and transferred to nylon filters (Biotrans ${ }^{\mathbb{B}}$; ICN Biomedicals, Inc. Irvine, CA) by capillary action (Maniatis et al., 1982). The filters were air dried for $20 \mathrm{~min}$ and subsequently baked for $2 \mathrm{~h}$ at $70-80^{\circ} \mathrm{C}$.

Complementary RNA for TIMP-1 and TIMP-2 was transcribed in vitro according to the protocol provided by the manufacturer (Stratagene, La Jolla, CA). For dot blot analysis, total cellular RNA $\left(1 \mu \mathrm{g} \mu \mathrm{l}^{-1}\right)$ isolated from individual corpora lutea were spotted as $2 \mu \mathrm{l}$ spots onto $0.2 \mu \mathrm{m}$ nylon filters [Biotrans $\left.{ }^{\mathbb{R}}(\mathrm{ICN})\right]$. In addition, RNA transcripts (cRNA; $2 \mu \mathrm{l}$ spots; $1000-7.8 \mathrm{pg}$ in bovine spleen $1 \mu \mathrm{g} \mu \mathrm{l}^{-1}$ total cellular RNA) and total cellular RNA isolated from bovine corpora lutea $\left(1-3 \mu \mathrm{l}\right.$ spots; $1 \mu \mathrm{g}$ total cellular RNA $\left.\mu^{-1}\right)$ were included as positive controls, and total cellular RNA isolated from bovine spleen $\left(2 \mu \mathrm{l}\right.$ spots; $I \mu \mathrm{g}$ total cellular RNA $\left.\mu \mathrm{l}^{-1}\right)$ was included as a negative control. Filters were allowed to air dry and then baked at $70-80^{\circ} \mathrm{C}$ for $2 \mathrm{~h}$.

Filters were prehybridized in $5 \times \mathrm{SSC}$ (Fisher Scientific), $0.05 \%(\mathrm{w} / \mathrm{v})$ Ficoll $400(\mathrm{Sigma}), 0.05 \%(\mathrm{w} / \mathrm{v})$ polyvinylpyrrolidone (Sigma), 0.05\% (w/v) BSA (Sigma), 0.1\% (w/v) SDS (Fisher Scientific), 50\% ( $/ \mathrm{v})$ deionized formamide (Fisher Scientific) and $50 \mathrm{mmol} \mathrm{NaPO} \mathrm{l}^{-1}$ (Fisher Scientific) with heat denatured herring sperm DNA (Fisher Scientific; $300 \mu \mathrm{g} \mathrm{ml}^{-1}$ ) overnight at $42^{\circ} \mathrm{C}$. The filters were hybridized with $2 \times 10^{\circ}$ c.p.m. $\mathrm{ml}^{-1}$ of appropriate $\left[{ }^{32} \mathrm{P}\right] \mathrm{CDNA}$ in prehybridization buffer (without herring sperm DNA) for $24-36 \mathrm{~h}$ at $42^{\circ} \mathrm{C}$. All filters were washed in $2 \times \mathrm{SSC}, 0.1 \% \mathrm{SDS}, 42^{\circ} \mathrm{C}$ for $20 \mathrm{~min}$, and $0.1 \times \mathrm{SSC}$, $0.1 \%$ SDS, $65^{\circ} \mathrm{C}$ for $30 \mathrm{~min}$. Filters were exposed to Kodak X-Omat AR-5 film for 1-5 days and subjected to densitometry.

\section{Determination of concentration of $m R N A$ for TIMP-1 and TIMP-2}

All mRNA concentrations were determined by comparing dot blot samples to a standard curve of in vitro synthesized cRNA on the same filter. Hybridization signals were measured by a video densitometer (Bio-Rad Laboratories). Coefficients of variation were $14.7 \%$ and $14.5 \%$ for TIMP-1 and TIMP-2, respectively.

\section{Statistical analysis}

Data were analysed by using Statistical Analysis Systems (SAS, 1985). Standard GLM procedures (analysis of variance)

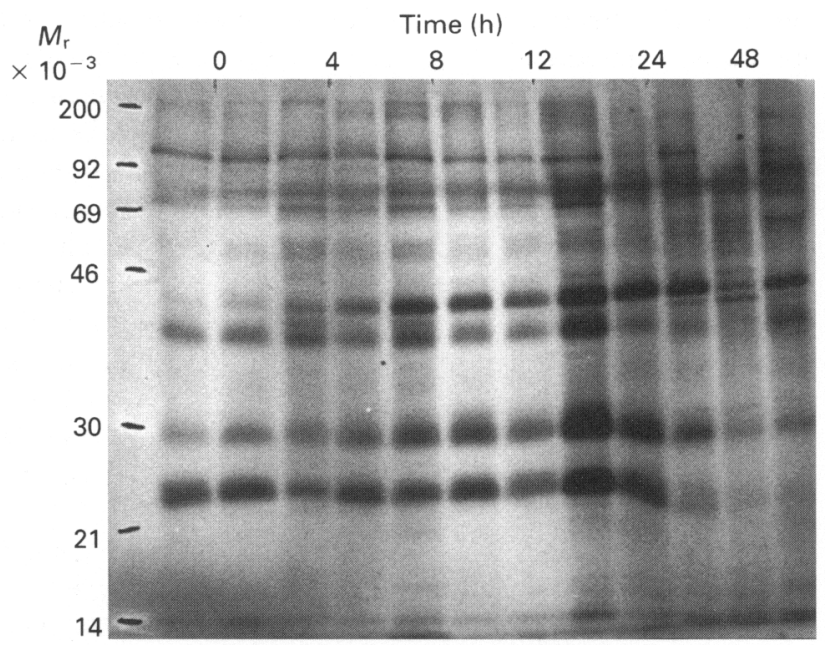

Fig. 1. Autoradiograph of $\left[{ }^{35} \mathrm{~S}\right]$ methionine-labelled proteins secreted from bovine corpora lutea during luteolysis. Two of five animals are shown for each time point. Time of removal of corpora lutea is indicated across the top. Migration of standard proteins are shown on the left.

were used and mean separation test (protected least significant difference) was used where applicable. Before analysis, percentages of density represented in protein bands were arcsin transformed; however, data are presented as means \pm SEM of percentages.

\section{Results}

\section{Serum progesterone concentrations}

Mean concentration of progesterone (SEM; $\mathrm{ng} \mathrm{ml}^{-\mathrm{I}}$ ) was not different among groups for any of the 4 days preceding or at the time of $\mathrm{PGF}_{2 \alpha}$ injection (range $2.6 \pm 0.3$ to $4.2 \pm 0.4$ ). At the time of surgery (tissue removal), serum concentrations of progesterone of the 0 and $4 \mathrm{~h}$ group were not different (3.0 \pm 0.5 versus $2.6 \pm 0.4)$, decreased $(P<0.01)$ in the $8 \mathrm{~h}$ group $(1.3 \pm 0.3)$, and remained low thereafter $(1.2 \pm 0.2$, $0.8 \pm 0.1$, and $0.6 \pm 0.2$ in the 12,24 and $48 \mathrm{~h}$ groups, respectively). These results were published by Juengel et al. (1993).

\section{Secreted proteins}

Tissue explants collected from all time points secreted a wide array of proteins (relative molecular mass $\left(M_{\mathrm{r}}\right)$ approximately 14300 to $>200000$; Fig. 1). Four major secretory products $\left(M_{\mathrm{r}} 21500,28200,43700\right.$ and 46000$)$ were chosen for one-dimensional scanning. Secretion of the $M_{\mathrm{r}} 21500$ protein(s) was greatest $(P<0.05)$ by the $0 \mathrm{~h}$ tissue explants compared with explants removed at later time points ( $12-48 \mathrm{~h}$; Table 1). Incorporation of $\mathrm{L}-\mathrm{f}^{35} \mathrm{~S}$ ]methionine into the protein(s) at $M_{\mathrm{r}} 28200$ was lower $(P<0.02)$ at $48 \mathrm{~h}$ than at any other time point. Secretion of the $43700 M_{\mathrm{r}}$ protein(s) did not change over time. The protein(s) at $M_{\mathrm{r}}$ of 46000 increased $(P<0.05)$ during luteal regression. 
Table 1. Percentage of total density (one-dimensional analysis) represented in selected secreted protein bands

\begin{tabular}{lcccccc}
\hline & \multicolumn{5}{c}{ Time after injection of $\mathrm{PGF}_{2 \alpha}(\mathrm{h})$} \\
\cline { 2 - 7 } $\begin{array}{l}\text { Molecular mass of } \\
\text { protein }\left(\times 10^{-3}\right)\end{array}$ & 0 & 4 & 8 & 12 & 24 & 48 \\
\hline & & & & & \\
21.5 & $16.2 \pm 2.8^{\mathrm{a}}$ & $13.2 \pm 1.0^{\mathrm{ab}}$ & $12.1 \pm 1.7^{\mathrm{ab}}$ & $11.1 \pm 0.9^{\mathrm{bc}}$ & $11.6 \pm 1.2^{\mathrm{ac}}$ & $7.0^{\mathrm{a}} \pm 1.4^{\mathrm{c}}$ \\
28.2 & $12.2 \pm 1.3^{\mathrm{a}}$ & $14.6 \pm 1.0^{\mathrm{a}}$ & $14.5 \pm 1.1^{\mathrm{a}}$ & $15.8 \pm 0.9^{\mathrm{a}}$ & $12.9 \pm 2.3^{\mathrm{a}}$ & $7.1 \pm 1.1^{\mathrm{b}}$ \\
43.7 & $13.3 \pm 1.0^{\mathrm{a}}$ & $11.9 \pm 1.6^{\mathrm{a}}$ & $10.4 \pm 1.4^{\mathrm{a}}$ & $11.5 \pm 0.9^{\mathrm{a}}$ & $8.0 \pm 0.8^{\mathrm{a}}$ & $11.0 \pm 2.1^{\mathrm{a}}$ \\
46.0 & $7.1 \pm 1.6^{\mathrm{a}}$ & $13.2 \pm 2.4^{\mathrm{b}}$ & $15.9 \pm 1.3^{\mathrm{b}}$ & $13.7 \pm 2.0^{\mathrm{b}}$ & $14.5 \pm 1.8^{\mathrm{b}}$ & $\mathrm{ND}$ \\
\hline
\end{tabular}

ND: not determined

a,b,cPercentages with different superscripts within a row are significantly different $(P<0.05)$.

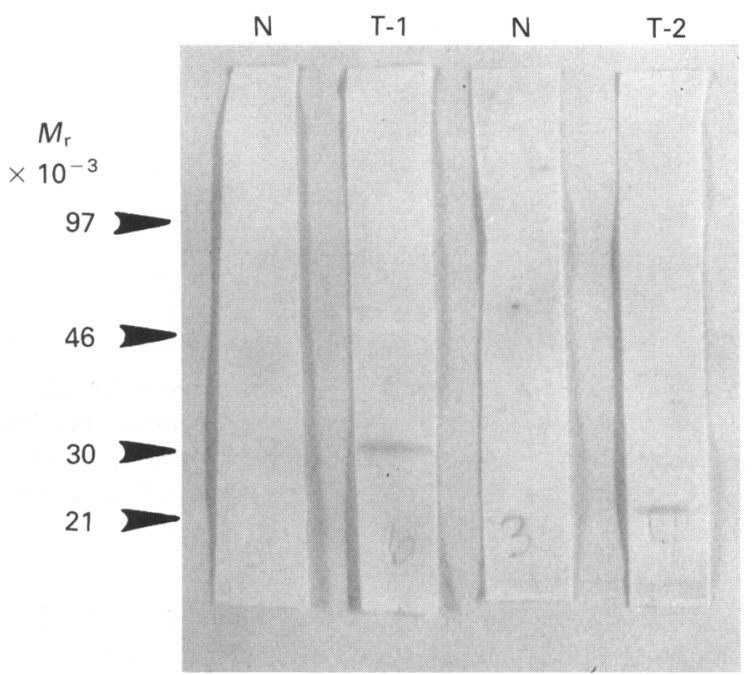

Fig. 2. Western blot analysis of in vitro secreted proteins $(100 \mu \mathrm{g}$ per lane) from corpora lutea collected $12 \mathrm{~h}$ after luteolysis was initiated. Nitrocellulose strips were incubated with normal rabbit serum $(N)$, tissue inhibitor of metalloproteinase (TIMP-1) antiserum (T-I), or TIMP-2 antiserum (T-2). Migration of standard molecular mass markers are indicated on the left.

\section{Western blot analysis of secreted luteal proteins for TIMP-1 and TIMP-2}

Since the ovine corpus luteum was found to produce TIMP-1 and -2 (Smith and Moor, 1991; Smith et al., 1992b, 1993), antibodies specific for TIMP-1 and -2 were used to provide evidence that the major secreted radiolabelled bands at $M_{\mathrm{r}} 28200$ and 21500 , respectively, were composed, at least in part, of these proteins. The TIMP-1 and TIMP-2 antisera specifically recognized proteins of $M_{\mathrm{r}} 28200$ and 21500 , respectively (Fig. 2).

\section{Expression of TIMP-1 and TIMP-2 $m R N A$ during luteolysis}

The ovine TIMP-I cDNA hybridized specifically to a band of approximately 900 bases in all sample lanes and in the positive control (Fig. 3). This transcript was similar in size to that previously reported in bovine corpora lutea (Freudenstein et al., 1990). There is a lack of hybridization in the negative
Fig. 3. Autoradiograph of bovine regressing corpus luteum total cellular RNA ( $7.5 \mu \mathrm{g}$ per lane) hybridized to ovine tissue inhibitor of metalloproteinase-1 (TIMP-1) cDNA. Time of removal of corpora lutea is indicated across the top. Migration of $28 \mathrm{~S}$ and $18 \mathrm{~S}$ ribosomal bands is indicated on the right. Film was exposed for 3 days.

control lane, bovine spleen (Fig. 3). Concentrations of TIMP-1 mRNA (ng $\mathrm{mg}^{-1}$ DNA) increased $(P<0.01)$ by $8 \mathrm{~h}$ after initiation of luteolysis, remained stable through $24 \mathrm{~h}$, then decreased $(P<0.05)$ at $48 \mathrm{~h}$ to concentrations similar to $\mathrm{Oh}$ (Fig. 4a).

The ovine TIMP-2 cDNA hybridized predominantly to a band of approximately 1100 bases in total cellular RNA isolated from tissue collected at all time points; however, a minor band of approximately 3500 bases was also detected. The size of the transcripts was similar to the reported size of TIMP-2 in other species; however, their relative intensities were reversed (Stetler-Stevenson et al., 1990). The negative 


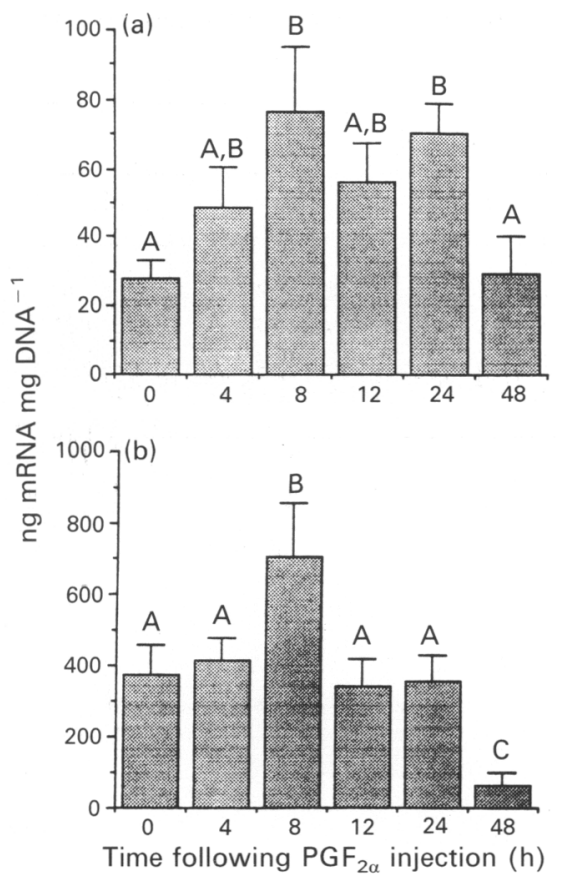

Fig. 4. (a) Mean concentrations of mRNA for tissue inhibitor for metalloproteinase-1 (TIMP-1) in bovine corpora lutea during luteolysis. (b) Mean concentrations of mRNA for TIMP-2 in bovine corpora lutea during luteolysis. Bars having different superscripts are significantly different $(P<0.05 ; n=5$ per time point).

control, bovine spleen, did not show any specific hybridization (Fig. 5). Concentrations of TIMP-2 mRNA (ng $\mathrm{mg}^{-1} \mathrm{DNA}$ ) were greatest $(P<0.05)$ at $8 \mathrm{~h}$ and lowest $(P<0.05)$ at $48 \mathrm{~h}$ (Fig. 4b).

\section{Discussion}

A number of points have emerged from these experiments. First, luteal tissue secretes a variety of proteins and the pattern of secretion changes during luteolysis. Changes in the pattern of protein production suggest a potential endocrine, paracrine, or autocrine role for these proteins during luteolysis. Fitz et al. (1993) found that treatment of ovine luteal cell cultures with the transcription inhibitor, actinomycin D blocks the ability of $\mathrm{PGF}_{2 \alpha}$ to inhibit progesterone secretion. Consequently, protein synthesis may be necessary for $\mathrm{PGF}_{2 \alpha}$-induced luteolysis. Second, although progesterone secretion was dramatically reduced, luteal tissue continued to secrete a number of proteins as late at $48 \mathrm{~h}$ after injection of $\mathrm{PGF}_{2 \alpha}$.

Secretion of a protein(s) of $M_{\mathrm{r}} 46000$ was observed, the pattern of secretion of which changed early during luteolysis. The potential role of the $46000 M_{\mathrm{r}}$ protein(s) in luteal regression may be determined upon its identification and characterization.

Two additional proteins that were shown to be produced by bovine corpora lutea during luteolysis included TIMP-1 and -2 . The relative molecular masses of TIMP-I $\left(M_{\mathrm{r}} 28000-\right.$ 30 000; Docherty et al., 1990) and -2 (21000; StetlerStevenson et al., 1990) in other species correspond closely

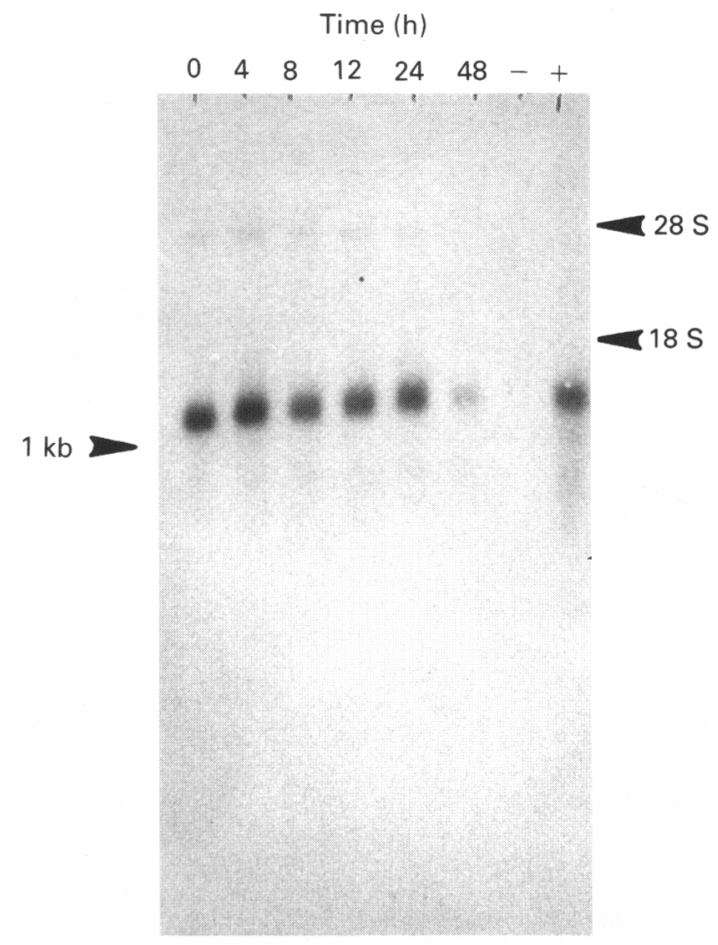

Fig. 5. Autoradiograph of bovine regressing corpus luteum total cellular RNA ( $5 \mu \mathrm{g}$ per lane) hybridized to ovine tissue inhibitor of metalloproteinase-2 (TIMP-2) cDNA. Time of removal of corpora lutea is indicated across the top. Migration of $28 \mathrm{~S}$ and $18 \mathrm{~S}$ ribosomal RNA is indicated at the right. Film was exposed for 5 days.

to the relative molecular masses of two proteins ( 28200 and 21500 , respectively) secreted by luteal tissue in this study.

Changes in expression of TIMP-I and -2 mRNA were detected during luteolysis. Metalloproteinases (collagenase, gelatinase, stromelysin) are metal-dependent enzymes that degrade the proteinaceous components of the extracellular matrix. These enzymes have an important role in tissue remodelling and TIMP-I and -2 are important regulators of metalloproteinase activity. It has been proposed that metalloproteinases and their inhibitors have an important physiological role in various processes including ovulation, implantation (reviewed in Sakamoto and Sakamoto, 1988), angiogenesis, cell migration and tumour cell metastasis (reviewed in Liotta et al., 1991; Liotta, 1992). In ovarian function, TIMP-1 and -2 may have an important role in regulating metalloproteinase activity preceding ovulation and in the regulation of tissue remodelling during the luteal phase. During luteolysis, corpora lutea undergo extensive tissue remodelling; it is therefore, not surprising that expression of TIMP-1 and -2 mRNA increased during this period.

As previously mentioned, there is evidence of apoptosis in bovine luteal tissue during luteolysis (Juengel et al., 1993). Cells undergoing apoptosis become detached from the extracellular matrix and begin to shrink (Kerr et al., 1972). Metalloproteinases and their inhibitors are considered to be associated with detachment of cells from the extracellular matrix. The transient increase in TIMP-1 mRNA precedes the onset of oligonucleosome formation, reported by Juengel et al. (1993). Proteins 
involved with regulation of tissue remodelling may, therefore, have an important role in apoptotic cell death of luteal cells.

In summary, protein production by corpora lutea changes during luteolysis. Two major secretory proteins of regressing corpora lutea have been identified as TIMP-1 and -2. Changes in protein expression may play an important role in luteal regression.

Contribution from the Missouri Agricultural Experiment Station Journal Series No. 11829.

\section{References}

Arends MJ and Wyllie AH (1991) Apoptosis: mechanisms and roles in pathology International Review of Experimental Pathology 32 223-254

Braden TD, Gamboni F and Niswender GD (1988) Effects of prostaglandin $\mathrm{F}_{2 \alpha}$-induced luteolysis on the populations of cells in the ovine corpus luteum Biology of Reproduction 39 245-253

Chomczynski P and Sacchi N (1987) Single-step method of DNA isolation by acid guanidinium thiocyanate-phenol-chloroform extraction Analytical Biochemistry 162 156-159

Copelin JP, Smith MF, Keisler DH and Garverick HA (1989) Effect of active immunization of pre-partum and post partum cows against prostaglandin $F_{2 \alpha}$ on lifespan and progesterone secretion of short-lived corpora lutea Journal of Reproduction and Fertility 87 199-207

Docherty AJP and Murphy G (1990) The tissue metalloproteinase family and the inhibitor TIMP: a study using CDNAs and recombinant proteins Annals of the Rheumatic Diseases 49 469-479

Fitz TA, Marr MM, Contois DF, Rexroad CE, Jr and Fritz MA (1993) Effects of individual and combined treatment with prostaglandins $E_{2}$ and $F_{2 \alpha}$ on progesterone secretion by ovine luteal cells supplemented with homologous serum lipoproteins in vitro Biology of Reproduction $\mathbf{4 8}$ 662-668

Freudenstein J, Wagner S, Luck RM, Einspanier R and Scheit KH (1990) mRNA of bovine tissue inhibitor of metalloproteinase: sequence and expression in bovine ovarian tissue Biochemical and Biophysical Research Communications $171250-256$

Hansel W, Alila HW, Dowd JP and Milvae RA (1991) Differential origin and control mechanisms in small and large bovine luteal cells Journal of Reproduction and Fertility Supplement 43 77-89.

Juengel IL, Garverick HA, Johnson AL, Youngquist RS and Smith MF (1993) Apoptosis during luteal regression in cattle Endocrinology 132 249-254

Kerr JFR, Wyllie AH and Currie AR (1972) Apoptosis: a basic biological phenomenon with wide-ranging implications in tissue kinetics British Joumal of Cancer 26 239-257

Knickerbocker JJ, Wiltbank MC and Niswender GD (1988) Mechanisms of luteolysis in domestic livestock. Domestic Animal Endocrinology 5 91-107

Labarca C and Paigen K (1980) A simple, rapid, and sensitive DNA assay procedure Analytical Biochemistry 102 344-352
Liotta LA (1992) Cancer cell invasion and metastasis Scientific American 266 $54-63$

Liotta LA, Steeg PS and Stetler-Stevenson WG (1991) Cancer metastasis and angiogenesis: an imbalance of positive and negative regulation Cell $\mathbf{6 4}$ $327-336$.

Maniatis T, Fritsch EF and Sambrook J (1982) Molecular Cloning. A Laboratory Manual Cold Spring Harbor Laboratory Publishing, New York

Moor RM, Osborn JC, Cran DG and Walters DE (1981) Selective effect of gonadotrophins on cell coupling, nuclear maturation and protein synthesis in mammalian oocytes Joumal of Embryology and Experimental Morphology 61 347-365

Murdoch WJ, Steadman LE and Belden EL (1988) Immunoregulation of luteolysis Medical Hypotheses 27 197-199

Niswender GD (1981) Mechanisms controlling luteolysis. In Dynamics of Ovarian Function pp 153-160 Eds NB Schwarts and M Hunzicker-Dunn Raven Press, New York

O'Shea JD, Nightingale MG and Chamley WA (1977) Changes in small blood vessels during cyclical luteal regression in sheep Biology of Reproduction 17 162-177

Riley JCM and Behrman HR (1991) Oxygen radicals and reactive oxygen species in reproduction Proceedings of Experimental Biology and Medicine 198 $781-791$

Sakamoto S and Sakamoto M (1988) Degradative processes of connective tissue proteins with special emphasis on collagenolysis and bone resorption Molecular Aspects of Medicine 10 301-428

SAS (1985) SAS User's Guide: Statistics Version 5 SAS Institute Inc, Cary, NC Sawyer HR, Niswender KD, Braden TD and Niswender GD (1990) Nuclear changes in ovine luteal cells in response to $\mathrm{PGF}_{2 \alpha}$ Domestic Animal Endocrinology $7229-238$

Smith MF and Moor RM (1991) Secretion of a putative metalloproteinase inhibitor by ovine granulosa cells and luteal tissue Journal of Reproduction and Fertility 91 627-635

Smith GW, McCrone S, Petersen SL and Smith MF (1992) Expression of mRNA encoding tissue inhibitor of metalloproteinases-2 (TIMP-2) by ovine preovulatory follicles and luteal tissue. In Serono Symposia IX Ovarian Workshop p 56. Chapel Hill, NC

Smith GW, Moor RM and Smith MF (1993) Identification of a $30,000 \mathrm{M}$ polypeptide secreted by cultured ovine granulosa cells and luteal tissue as a tissue inhibitor of metalloproteinases Biology of Reproduction 48 125-132

Smith GW, Goetz TL, Anthony RV and Smith MF (1994) Molecular cloning of an ovine ovarian tissue inhibitor of metalloproteinases: ontogeny of messenger ribonucleic acid expression and in situ localization within preovulatory follicles and luteal tissue Endocrinology 134 344-352

Stetler-Stevenson WG, Brown PD, Onisto M, Levy AT and Liotta LA (1990) Tissue inhibitor of metalloproteinases-2 (TIMP-2) mRNA expression in tumor cell lines and human tumor tissues Journal of Biological Chemistry 265 13933-13938

Wiltbank MC, Diskin MG and Niswender GD (1991) Differential actions of second messenger systems in the corpus luteum Journal of Reproduction and Fertility Supplement $\mathbf{4 3}$ 65-75

Woessner JF, Jr (1991) Matrix metalloproteinases and their inhibitors in connective tissue remodeling FASEB Journal 5 2145-2154 